\title{
Socio- Political Education and Women Empowerment in Buddhist Perspective
}

\author{
Sitthiporn Khetjoi ${ }^{1}$, Worachat Thasa $^{2}$, Saccarak Raisa-nguan ${ }^{3}$, Phattharachai Uthaphan ${ }^{4}$ \\ ${ }^{1,2}$ Faculty of Social Science, Mahamakut Buddhist University Isan Campus, \\ ${ }^{3}$ Faculty of Education, Mahamakut Buddhist University Isan Campus, \\ ${ }^{4}$ Graduate School, Mahamakut Buddhist University Isan Campus \\ Email: ${ }^{1}$ piakealexander@yahoo.com, ${ }^{2}$ Worachat @ gmail.com, ${ }^{3}$ rakrevata1978@gmail.com, ${ }^{4}$ phattrachan@hotmail.com
}

\begin{abstract}
The purpose of research was to study the socio-political education and women empowerment in Buddhist perspective. The researchers studied and collected the data from Buddhist scriptures, texts, and related document about socio-political education and women empowerment in Buddhist perspective and analyzed by using content analysis. The results indicated that For decades, women have been parts of the supply of cheap, unskilled or semi-skilled labors for the industrial and service sectors. Gender discrimination continues even in the present times. At the same time, the problems of rural and urban lower-class women cannot be ignored. The empowerment of women is one of the solutions to the problems of inequality, subordination and marginalization that women face in the society. However, this kind of empowerment is only partial for all though they have economic and political power, they are kept out of decision making or they are dependent on their husband, father or brother for crucial decisions. Buddhism accepts that every human being, independent of the consideration of sex, gender, class etc. is composed of five elements (Paṇcakkhandhā): namely rupa skandha, samjṇa skandha, vedanā skandha, samiskāra skandha and vijṇanā skandha. On this basis, Buddhism has advocated the equality between man and women and thus has transcended the gender difference. It treats man and woman equally. Buddhism reflected in the Buddhist scriptures that there is a biological difference between women and men, but they have similar intellectual, mental as well as spiritual capabilities.
\end{abstract}

Keywords

Buddhist Perspective, Empowerment, Socio-Political Education.

Article Received: 10 August 2020, Revised: 25 October 2020, Accepted: 18 November 2020

\section{Introduction}

The increasing influence and relevance of Buddhism in its various forms in the global society of the 21 st century have given rise to a vibrant and evolving movement. In the field of gender and development, an understanding of the influence that religious and cultural traditions have upon women's social status or economic opportunity is slowly being recognized as an important factor in the pursuit of female empowerment in developing countries. While institutional religion can legitimize values and rules that disempower women, the importance of religion in the lives of millions of poor women across the globe means that secular feminism is often perceived not only as western but also as lacking cultural relevance [1] .Over the last few decades Buddhism, environmentalism, the ecological movement and feminism have been the subject of much interdisciplinary work. Buddhist philosophy, ethics and its system of meditation have found common ground with the movements known as Eco-Buddhism and deep ecology with the core acknowledgement of the interrelatedness of all beings and their intrinsic value for the health and survival of the planet and all its inhabitants. The increasing influence and relevance of Buddhism in a global society have given rise to a vibrant and evolving movement, particularly in the west, loosely called Socially Engaged Buddhism. Today many looks to Buddhism for an answer to one of the most crucial issues of all time-eradicating discrimination against women. There is general agreement that Buddhism does not have a reformist agenda or an explicit feminist theory. The researchers explored this issue from a Theravāda Buddhist perspective using the scriptures as well as recent work by Buddhist scholars conceding that there are deep seated patriarchal and even misogynistic elements reflected in the ambivalence towards women in the Pâli Canon and bias in the socio-cultural and institutionalized practices that persist to date in Theravāda Buddhist countries. However, Buddha's acceptance of a female monastic order and above all his unequivocal affirmation of their equality in intellectual and spiritual abilities in achieving the highest goals clearly establish a positive stance. While social and legal reforms are essential, it is meditation that ultimately uproots the innate conditioning of both the oppressors and the oppressed as the Dhamma at its pristine and transformative core is genderless [2]. However, compared to the other major religions, the women have always played a significant role in Buddhism as lay disciples as well as monastics later on influencing the Order and societies where Buddhism took root [3]. Dewaraja also notes that unlike in the other major religions, marriage is a purely secular matter in Buddhism, and also cites the Sigalovāda Sutta where the marital relationship is described as a reciprocal one with mutual obligations, and as there is no central creator in Buddhism and hence no sacredness attached to the human body [4] nor a strong differentiation of what is natural or unnatural, Buddhism has nothing against contraception [5] [6] or homosexuality .Most of all, the mere fact of women being included in the teachings and practices was remarkable given that this took place over 2,500 years ago in a patriarchal society where women had few rights with regard to education and religious practices as Buddhism's greatest contribution to the social and political landscape of 
ancient India is the radical. All men and women, regardless of their caste, origins, or status, have equal spiritual worth [7]. This is especially pertinent concerning the status of women, who were traditionally prevented by the brāhmanas from performing religious rites and studying the sacred texts of the Vedas. A core positive characteristic of Buddhism with regard to gender equality is the absence of an omnipotent Creator God traditionally portrayed as a male at its centre providing legitimacy to male supremacy. While the main agenda of Buddhism is not social reform, its ethical, doctrinal and psychological frameworks explicitly condemn creating mental or physical suffering for any other being, and the key concepts that suffuse the Dhamma are harmlessness (ahimsā), mettā (universal loving kindness) and compassion (karunā). Buddhism becomes an increasingly relevant globalized force with the scriptures of all schools available freely to so many and both lay and monastic women taking on key roles, it is inevitable that outdated prejudice and barriers begin to crumble which is essential for the flourishing of Buddhism in the 21st century. The Buddhist perspective on empowerment has efficiently provided possible solutions for these problems. For example, the ambivalent attitude of women to other women and also the societal ignorance about the capacities of a woman needs to be removed. Buddha's teaching offers the methods of practical solutions to all housewives and nuns and also to the society of modern times. The perspective into Buddhism will enable the society to remove the ignorance towards women and rekindle the spirit of wisdom towards the roles and responsibilities of women.

\section{Research Objective}

The purpose of research was to study the socio-political education and women empowerment in Buddhist perspective.

\section{Research Methodology}

The researchers attempted to study and analyzed from the Pālī Buddhist literatures which are the primary sources together with the commentaries of related works. In addition to the Buddhist literature, the literature on feminism and gender studies have also been considered to understand the concept of empowerment. Also the researchers studied and analyzed from Pālī Tripitakas, Nikāyas, and commentaries.

\section{Results}

\section{Women in Buddhist Perspective}

Buddhism, in its origins, was a pragmatic soteriology, a theory of liberation that sought to free humanity from suffering, first by thoroughly analyzing the fundamental human predicament and then by offering a practical method or path for eliminating the afflictions cognitive and dispositional that are perpetuated as greed, hatred, and delusion. The Buddha was frequently critical of conventional views including those carrying the authority of Brahmanic tradition. In marked contrast to the sacerdotal ritualism of the Brahmins, he offered a path that was open to all. The first canonical attitude to consider, soteriological inclusiveness, thus arguably is the most basic and also the most distinctively Buddhist attitude regarding the status of women that one can fine in the vast literature of the 2500 year old tradition. The earliest Buddhists clearly held that one's sex, like one's caste or class (varna), presents no barrier to attaining the Buddhist goal of liberation from suffering. Women can, affirmed by the Buddhist tradition, pursue the path. Moreover, they can become arhats, Buddhist saints who had broken completely the cycle of the suffering of death and rebirth (samsāra) [8]. In fact, the position that femaleness is no barrier to the achievement of the Buddhist human ideals takes two forms in Buddhist texts. The more common variation on this theme essentially proclaims that the Dhamma is neither male nor female that gender is irrelevant or even non-existent when one truly understands Buddhist teachings. One also finds infrequent claim that in fact, for those with good motivation, femaleness is actually an advantage. Though that assessment is not by any means common or well- known, its very existence is important for gathering the fullness of an accurate record of Buddhist attitude toward gender. In addition, the Buddha's main argument against this was that no man or woman could be superior or inferior in society merely by reason of his birth

The Buddhist view about woman's nature pointed out that despite the fact that the Buddha elevated the status of women; he was practical in his observations and advice given from time to time. He realized the social and biological differences between men and women. The reality of the fact of the nature of women was brought out by the Buddha who had pointed out not only their weaknesses, but also their abilities and potential. The Buddha did not talk about the concept of spiritual empowerment of woman but the investigations of epistemological and metaphysical considerations behind the Buddhist thoughts enable us to understand the Buddhist concept of empowerment. This concept of empowerment will enable us, further; to solve the problems that arise in a woman's life 2500 years ago he laid down his thoughts about women that were substantial enough to guide feminist thoughts and movements.

\section{Social Empowerment of Women in Buddhism}

As we have seen that empowerment of woman is attained through her self-realization that is through her mental and spiritual development and through her knowledge of herself and of the society as well as the realization of society and its acceptance that woman also has her own independent existence. Her self-realization makes her aware of her attributes; her qualities belong to her and not these that are imposed on her by social and cultural conventions and through the processes of enculturation and socialization. When the woman and the society have clear understanding regarding the nature of each other then only, there is holistic development of society as well as of the members of the society.

The Buddha through his discourses always tried to enlighten the people about the myth of gender difference. In Buddha's time, the birth of female child was not welcomed. Her birth made the parents unhappy. It may be because the parents believed that after marriage, daughters went to their husband 
house then who would take care of the parents in their old age. But if they had son, their son lived with them even after their marriage. So, the sons could take care of them. It is because of this belief, parents preferred the male child. The Buddha tried to remove this kind of belief from the mind of people.

According to him, there was no reason to feel gloomy at the birth of a daughter. For example, King Pasenadi was unhappy at the time of birth of a girl to his Queen Mallikā. He went to the Buddha to tell this news and when the Buddha observed that King is unhappy, he said;

"Indeed, a woman of a certain sort is better than a man lord of folk: Wise, Virtuous, reversing her husband's mother, a devoted wife, the man born of her is a hero, ruler of the regions, such a son of a good wife is one who advised his realm"'[9].

\section{Political Empowerment of Women in Buddhism}

The Buddha acknowledged the independent religious status to women, but his views with regard to the political status of women remained conventional. We don't have many references about the political status of women in Buddhism. However, Srimālā, in Mahāyāna Buddhism held the position of queen. This consolidates the view that Buddhism did give equal status to women.

A woman could rule a kingdom. As secular women, their only business was to pure themselves as good housewives and affectionate mother. The truth is that Gautama was least interested in temporal matters. For him systems of governments did not appeal much. He did not care what general position of women or even men was in the social or political fabric of the country.

In the extensive kingdom of the great Buddhist monarch Asoka, it is not found that any office of significance was ever occupied by any woman. In the noble mission of propagating the Buddhist doctrine far and wide women travelled to every nook and corner of the globe and mixed with every sort of people, putting away all the gender differences. They preached to all men and women and expounded the doctrine in a worthy manner. Although, women held eminent religious position, the lay-sisters in the world had no respectable status to enjoy. Nothing was done by any law-giver to improve their secular existence and to ensure their general welfare. Thus, all went on as usual, without any betterment of the secular status of women. As we can see, Śrī mālā the Queen of Andhra, belonging to first century had important contribution to the development of the Buddhist thought [10].

\section{Educational Empowerment of Women in Buddhism:}

As a whole, woman in Buddhism enjoyed higher status, greater freedom, more equality and an enhanced liberal environment than in the preceding ages. Women were more empowered in the Buddhist period. Buddhism's contribution to the liberation and uplift of the woman in the social and educational sectors was equally immense. In this respect, the elevation of the woman in the Buddhist set up was conceptually much nobler, it was much more than a question of 'rights' and 'duties'. The Buddhists really respect interpersonal relationships and therefore do not desire to tear away any portion of society and isolate it. For Buddhism, it is an achievement in the total integration the woman into the social fabric of the human community. The family in this respect is the smallest unit. In Buddhist thinking the male's respect for the female had to be so high that the Buddhists knew what was meant by the courteous behavior to women. The ladies therefore had to be treated with due courtesy and consideration. Women under Buddhism had maintained their traditional legal position and the laws of the land had not change in the favour changed on this respect. In the Buddhist ages, women enjoyed religious and educational independence and spiritual and ethical advancement but in other spheres such as social, political and economic the situation remained the same as it was in the preceding ages. Overall, the rise of Buddhism brought an improvement in the status of women. Through its practices, it has also facilitated the self-confidence, empowerment and spiritual and educational liberation of both women and men such as Mahāpajāpatī Gotamī, the Buddha's maternal aunt and foster mother, Khemā, the queen of king Bimbisāra of Rajgriha, Pațāchārā from Shravasti; proficient in duties, Bhaddā Kuṇụalkeshā, Ambapālī and Isidās̄i have attained positions of high repute in the religious order of Buddhism. Sāmāvatī from Bhaddiya, Khujjuttarā and Visākhā are known for their devotion and charitable deeds [11]. Buddhism does not restrict either the educational opportunities of women or their religious freedom. The Buddha unhesitatingly accepted that women are capable of realizing the Truth, just as men are. This is why he permitted the admission of women into the Order, though he was not in favour of it at the beginning because he thought their admission would create problems in the Sasana. Once women proved their capability of managing their affairs in the Order, the Buddha recognized their abilities and talents, and gave them responsible positions in the Bhikkhuni Sangha. The Buddhist texts record of eminent saintly Bhikkhunis, who were very learned and who were experts in preaching the Dhamma. Dhammadinna was one such Bhikkhuni, Khema and Uppalavanna are two others [12].

\section{Conclusion}

Buddhism has accepted that women are as eligible for spiritual emancipation as men and women, both can follow the Four Noble Truths, the Right Eightfold Path, surrender to the three jewels - the Buddha, the Dhamma and the Sañgha, cultivate the Pañcasīla and possess the three Jewels of Sīla, Samādhi and Paññā, and become eligible to emancipate through meditation[13].The empowerment of women is one of the solutions to the problems of inequality, subordination and marginalization that women face in the society. However, this kind of empowerment is only partial, for all though they have economic and political power, they are kept out of decision making or they are dependent on their husband, father or brother for crucial decisions. Hence in order to change this situation, it is necessary that women have to realize their own nature and understand the value of their own existence. When they realize their own nature they will have confidence and will participate in decision making independently. This will be possible only when they will be empowered spiritually. However, this also means to bring a significant change in the social mentality. Many a time, a 
woman has confidence and has realized her own potential, but society prohibits and blocks her progress, her problems cannot be solved. In other words, to solve the problems of the woman, and in order to empower her it is also necessary that the society has to change its patriarchal mentality. The Buddha did not talk about the concept of spiritual empowerment of woman, but the investigations of epistemological and metaphysical considerations behind the Buddhist thoughts enable us to understand the Buddhist concept of empowerment. This concept of empowerment will enable us to solve the problems that arise in a woman's life 2500 years ago. He laid down his thoughts about women that were substantial enough to guide feminist thoughts and movements.

\section{References}

[1] Peach, L. J. Human rights, religion and (sexual) slavery', Annual of the Society of Christian Ethics, 2000.

[2] Chand R. Sirimanne. Buddhism and Women: Dhamma has no Gender. Journal of International Women's Studies. Vol.18 no.1,2016, p.273. Retrieved 11 September 2019.from https://vc.bridgew.edu/cgi/ viewcontent.cgi article $=1923 \&$ context $=\mathrm{ji}$ ws.

[3] Dewaraja, LS. The position of women in Buddhism', Access to Insight (Legacy Edition),1994.Retrieved11 September 2019.From

http://www.accesstoinsight.org/

lib/authors/dewaraja/wheel280.html.

[4] Gross, RM. Buddhism after patriarchy: a feminist history, analysis, and reconstruction of Buddhism, State University of New York Press, 1993.

[5] Hughes JJ \& Kewon D. Buddhism and medical ethics: A bibliographic introduction, Journal of Buddhist Ethics, vol. 2,1995: 105-124, Retrieved12 September 2019. From http://www.buddhistethics.org/2/hughes.tx t.

[6] Harvey, P. An introduction to Buddhist ethics: Foundations, values and issues. Cambridge University Press, 2000.

[7] Halkias. The Enlightened sovereign. Buddhism and kingship in India and Tibet', in SM Emmanuel (ed.), A companion to Buddhist philosophy, John Wiley \& Sons. Inc. Oxford, 2013.

[8] José Ignacio Cabezón. Buddhism, Sexuality and Gender, State University of New York Press, Albany, 1992.

[9] Sharma, S. Ram. Women and education, Discovery Publishing House, 1995.

[10] Phra Somchan Saenphan. Buddhist Perspective on Empowerment of Women with Special Reference to Early Buddhism. Department of Philosophy, Savitribai Phule Pune University, 2012.Retrieved 20 September 2019.From http://hdi.handle.net/10603/81400

[11] K. T. S. Sarao. Origin and nature of ancient Indian Buddhism, Munshiram Manoharlal Publishers, 2010.

[12] Buddhism and Women. Position of The Women at the Time of Buddha, Retrieved 21 September 2019, From http://www.buddhanet.net/elearning/history/position.htm.

[13] Merriam-Webster. Merriam-Webster's Encyclopedia of World Religions, Library of Congress Cataloging in Publication, 1999. 